\title{
Characterization of the different behaviours exhibited by juvenile grey mullet (Mugil
} cephalus) under rearing conditions

4 Jessica A. Jimenez-Rivera ${ }^{1,3}$, Anaïs Boglino ${ }^{3}$, Joel F. Linares-Cordova ${ }^{3,4}$, Neil J. Duncan ${ }^{5}$, María de Lourdes Ruiz-Gómez ${ }^{6}$, Sonia Rey Planellas ${ }^{7}$ Zohar Ibarra-Zatarain²*

6

$7 \quad{ }^{1}$ Posgrado en Ciencias Biológico Agropecuarias, Universidad Autónoma de Nayarit, 63155 Tepic,

8 México

$9{ }^{2}$ CONACYT-UAN-Nayarit Centre for Innovation and Technological Transference (CENITT), 10 Av. E González s/n. CP 63173. Tepic, México

$11{ }^{3}$ Nayarit Centre for Innovation and Technological Transference (CENITT), Av. E González s/n.

12 CP 63173. Tepic, México

134 Posgrado de Ciencias Agropecuarias, Colegio de Ciencias Agropecuarias, Universidad 14 Autónoma de Sinaloa, Km 17,5, CP 8000 Culiacán, México

$15{ }^{5}$ IRTA, Sant Carles de la Ràpita, Carretera de Poble Nou, km 5.5, 43540 Sant Carles de la Ràpita,

16 Tarragona, Spain

$17{ }^{6}$ Laboratorio de Ecología y Conducta, Facultad de Ciencias, Universidad Autónoma del Estado de

18 México, Toluca, Estado de México, México

$19{ }^{7}$ Institute of Aquaculture, Faculty of Natural Sciences, University of Stirling, FK9 4LA, Stirling, 20 Scotland, UK

24 *Corresponding author: zohar.ibarra@ gmail.com; tel: +52 6692407280

25

26

27

28

29

30 


\section{Abstract}

This research described the common behaviour of grey mullet (Mugil cephalus) under rearing conditions. The different behaviours exhibited by mullets were videorecorded with

36 submersible cameras installed inside of three tanks. A total of 690 minutes per day (07:30 - 18:30

37 hours) were recorded per tank during a week. Afterwards, an ethogram was elaborated to organize

38 the different behaviours exhibited by juvenile $M$. cephalus, with two general categories: a)

39 locomotion, including three different observed behaviours (resting, swimming and fast swimming)

40 b) feeding, including three behaviours (surface feeding, bottom feeding and rubbing). The video

41 recordings showed that $M$. cephalus is a species with a constant locomotion associated to feeding,

42 since they showed constantly movement during most of day light period the opposite to dark 43 periods. Mullets were observed to be a non-aggressive fish species, due to the absence of 44 dominance and aggression towards conspecifics, resulting in a high predisposition for adaptation

45 to captivity. Finally, behavioural frequencies of grey mullet's juveniles were not significantly 46 different among the three tanks for most of the behavioural variables analysed $(p>0.05)$ except for 47 the variable bottom feeding $(p=0.02)$. Results from this study could be of interest to the aquaculture 48 industry to implement protocols and to optimize rearing techniques for the production of grey 49 mullet.

51 key words: welfare, behaviour; grey mullet; rearing conditions; ethogram

\section{Introduction}

Mugil cephalus, commonly known as grey mullet, is a cosmopolitan fish species. It is found

56 in all oceans and in a large variety of aquatic environments. It has a high tolerance to different

57 environmental conditions that includes a wide range of temperatures and salinities (Saleh, 2008).

58 These eurytopic attributes of grey mullet, in combination with the foraging feeding habits and fast-

59 growing rate $(\sim 0.70 \mathrm{~kg}$ per year), enable this species to be considered for both freshwater and 60 marine aquaculture (Whitfield et al., 2012; FAO, 2020a). Overall, grey mullet has been used as a 61 model in different research areas, such as ecotoxicology, population dynamics, parasitism and 62 gametes cryo-preservation (Chao \& liao, 2001; Mahanty et al., 2011; Crosetti \& Blaber, 2015; 
63 Colin et al., 2020). However, the interest for human consumption has increased during the last 64 decade and data provided by FAO (2020b) showed that grey mullet fisheries has increased in the 65 last decade from 101,182 tons in 2008 to 130,233 tons worldwide in 2018. This increasing number 66 of captures has led to a growing interest by the aquaculture industry for developing techniques and 67 protocols to produce fingerlings in captivity. In this context, mullet aquaculture production was of 68 13,681 tons in 2016, where Egypt being the main producer, followed by the Republic of Korea, 69 Italy, the Chinese Province of Taiwan and Israel (Crosetti, 2015; FAO, 2020a). Likewise, in some 70 countries the polyculture practices of Mugil cephalus (Soto, 2009) with other species such as 71 Penaeus vannamei (Hosseini Aghuzbeni et al., 2017), Penaeus monodon (Mondal et al., 2020) 72 turn out to be a sustainable alternative.

The economic importance of Mugil is based on its consumption and its cost varies from one region to another, relying on several factors; for example, female's grey mullet gonads, also known as caviar or bottarga, could reach $65 €$ per kg in the European markets (Aldana, 2015; Rodríguez, 2018). Therefore, significant advances have been made on nutrition, growth, larval culture and reproduction of individuals reared in captivity (Martínez et al., 2019; Talukdar et al., 2020; Besbes et al., 2020; Ramos-Júdez et al., 2021). Furthermore, several studies have demonstrated that grey

80 mullet can also be an adequate candidate species for mariculture which can contribute to food 81 production and the reduction of fishing impact (Saleh, 2008; Robles \& Mylonas, 2017).

For domesticating and rearing a fish species, welfare is important, since confinement 84 conditions trigger physiological and behavioural responses which impact growth performance, 85 diseases outbreaks, reproduction, among other factors (Ashley, 2007). It has also been recognized 86 that most of the typical behaviours exhibited by organisms in captivity, such as: feeding, 87 swimming, sociability, dominance, reproduction, etc., are related to environmental stimuli and 88 aquaculture management practices (Rowland, 1999; Lall \& Tibbetts, 2009; Baran \& Streelman, 89 2020). Additionally, the behavioural responses of individuals under rearing conditions are often 90 used as operational welfare indicators, since they might indicate potential stressful situations of 91 individuals in their environment (Huntingford et al., 2006). Hence, understanding the behaviour 92 of cultured species can be an early warning of alterations in animal stress status and health, and a 
93 useful tool to provide adequate environmental conditions and facilities promoting welfare of the

94 reared organisms (Kristiansen et al., 2004; Saraiva et al., 2019).

In behavioural studies, ethograms provide reliable information about the behavioural responses of animals in their environment. According to McDonnell \& Poulin (2002), an ethogram could be defined as a formal description of a species behavioural repertoire or a major segment of it. It may be a complete list of all behaviours or it may focus on particular functional classes of behaviours. Therefore, an ethogram shows the actions, interactions and overall activity typically performed by animals in the wild and such responses are expected to be replicated in captivity (Marsh \& Hanlon, 2004). Currently, ethological studies of fish in captivity includes the analysis of behavioural functional categories, such as reproductive behaviours (Ibarra-Zatarain \& Duncan, 2015) or feeding characteristics (Huntingford, 2004; Carvalho et al., 2007). However, studies that analyse in detail the common behaviour exhibited by the organisms under captivity conditions are scarce or inexistent for many species that are currently produced in aquaculture (Lahitte et al., 2002; Bolgan et al., 2016). In the case of M. cephalus, there are no studies describing the common behaviour of this species in the wild or under rearing conditions. Therefore, it is relevant to describe the behaviour of this species in captivity, since it represents a forecasting tool to evaluate the preferences and requirements of the animals, to provide adequate management protocols and

112 of this study was to generate an ethogram that described the common behavioural exhibited by 113 juveniles of grey mullet Mugil cephalus in rearing conditions.

\section{Materials and methods}

\section{Ethic statement}

120 following the criteria of the National Centre for the Replacement, Refinement and Reduction in 121 Animals in Research (NC3Rs, U.K.). Locally, the protocol for handling and use of animals was 122 authorized by the Bioethics Commission of the State of Nayarit, Mexico (permit number CEBN / 123 05/2017). 


\section{Collection and maintenance of organisms}

125

126

127

128

129

130

131

132

133

134

135

136

137

138

139

140

141

142

143

144

145

146

147

148

149

150

151

152

153

154

Fish were captured from the wild on the pacific coast, Mazatlán, Mexico, in September 2019. A total of 300 fish were caught (average weight and length $30.2 \pm 6.9 \mathrm{~g}$ and $15.1 \pm 1.2 \mathrm{~cm}$, respectively). Fish were transported to the Nayarit Centre for Innovation and Technological Transference (CENITT-UAN) in Tepic, Nayarit. Individuals were acclimated in two 500L rectangular tanks $(100 \times 140 \times 55 \mathrm{~cm})$ connected to a recirculation system (RAS). Once acclimation was completed (45 days), a total of 36 fish were randomly selected and transferred to three $220 \mathrm{~L}$ rectangular tanks $(80 \times 68 \times 48 \mathrm{~cm})$ to reach a final density of 12 fish per tank during the experiment. Water parameters were maintained as follows: temperature: $25-27^{\circ} \mathrm{C}$, salinity: $27-$ 29 ppm, pH: 6-7 and oxygen 5-7 mg / L. All water parameters were monitored daily in the morning. Photoperiod was adjusted to follow the natural seasonal cycle (Light: Dark, 11: 13) by using an automated external dimmer (MyTouchSmart, General Electric () ) turning on-off white lamps (OSRAM 85Watts) at 08:00 - 19:00 hours during the experiment. Mullets were fed to satiety with a commercial diet designed for marine fish (specifications: floating pellets, 55\% crude protein, $3.00 \mathrm{~mm}$; Skretting®, The Netherlands). Tanks were siphoned each day, $30 \mathrm{~min}$ before the first feeding and $30 \mathrm{~min}$ after the last feeding, to remove the remains of food and faeces and to maintain adequate water quality conditions.

\section{Description of behaviour in grey mullet (Mugil cephalus)}

\section{Data collection}

A high-definition camera system (Swann/2K Series-1080p) was installed in three tanks. Each camera was positioned on the lateral wall of the tank, $10 \mathrm{~cm}$ below the water surface in order to capture more than $90 \%$ of the total area of the tank. Video recording started at 07:30 and finalized at 19:00 $\mathrm{h}$ every day for one week. The selection and quantification of behavioural variables were based on focal observations of the video recordings performed by three distinct observers, whom reported traits of the behavioural repertoire of the organisms. It included feeding habits, swimming and overall activity at the beginning and end of seven consecutive days, following the recommendations of Bolgan et al. (2016). A total of 690 minutes per day were 
155 recorded from each tank, comprising 90 video analysis per experimental unit (Mas-Muñoz et al.,

156 2011; Ibarra-Zatarain \& Duncan, 2015; Thomsen et al., 2020).

157

\section{Behavioural variables}

159

The behavioural variables analysed and selected were based on Altman (1974), and were grouped in two categories: 1) locomotion and 2) feeding. For the first category (Table 1), three behaviours were evaluated and quantified: i) resting, ii) swimming and iii) fast swimming. For the second category (Table 1), three behavioural variables were evaluated: i) surface feeding, ii) bottom and feeding iii) rubbing. These behavioural variables were selected and adapted from previous descriptive studies on behaviour with other marine and freshwater fish species, such as the bicolour damselfish Eupomacentrus partitus (Myrberg, 1972), common sole Solea solea (MasMuñoz et al., 2011), some reef fishes (Pink \& Fulton, 2014), gilthead seabream Sparus aurata (Ibarra-Zatarain \& Duncan, 2015) and artic charr Salvelinus alpinus (Bolgan et al., 2015).

\section{Statistical analysis}

Statistical analyses were performed using IBM SPSS Statistics 25 software. Data were checked for normality and homoscedasticity with a Kolmogorov-Smirnov test and a Levene's test,

174 respectively. A multivariate analysis of variance (MANOVA) was performed to assess the 175 uniformity in the behaviours analysed among the three tanks where the cameras were installed. 176 Additionally, a Tukey's post-hoc test was performed on data when significant differences were 177 detected among tanks. A 95\% confidence interval $(p=0.05)$ was set for all analyses.

\section{RESULTS}

\section{General behavioural observations}

Mugil cephalus exhibited a stationary swimming behaviour or resting during the periods

184 with no illumination before and lights were switched on and off (07:30 to 08:00 and 18:30 to 19:00 185 hours, respectively). Locomotor activity of grey mullet juveniles increased gradually during the 
186 day and this behaviour was similar in all tanks throughout the experiment. Additionally, mullets

187 were observed to be a social, non-aggressive and highly active fish species.

\section{Description of behaviour}

190

\section{Locomotion}

Resting. This behaviour was mainly characterized by stationary swimming, where fish pectoral and tail fins remained close to their body with slow undulations. Fish maintained a stationary position in the water column; however, in a few occasions, they performed slow movements. Moreover, fish did not exhibit social interactions, since they occupied different positions in the water column (Fig. 1-A, Table 1). This inactivity occurred always in the absence of light, before 08:30 and after 18:40 hours and could be described as fish sleep (Keene \& Appelbaum, 2019).

Swimming. This behaviour was characterized by active swimming, in which fish swam at a constant speed throughout the tank. Additionally, mullets formed small groups or fish shoals with 202 some individuals swimming independently. While fish were swimming, they took different 203 directions and interacted with other individuals in repeated occasions. Moreover, no aggressive 204 behaviours such as chases, bites, fin erections, etc. were detected. This behaviour was observed in 205 daylight hours, between 08:45 and 18:30 hours (Fig. 1-B, Table 1).

Fast swimming. This is defined as high fish activity or fast swimming, in which fish 207 presented a subcarangiform locomotion consisting in constant undulations of the posterior part of 208 the body, accompanied by movements of the tail fin and with or without extensions of pectoral 209 fins. Fish showed prolonged movements from one point to another in the water column, with 210 constant interactions between fish, but with no aggression. This behaviour occurred approximately 21130 minutes before a feeding event (Fig. 1-C, Table 1). 


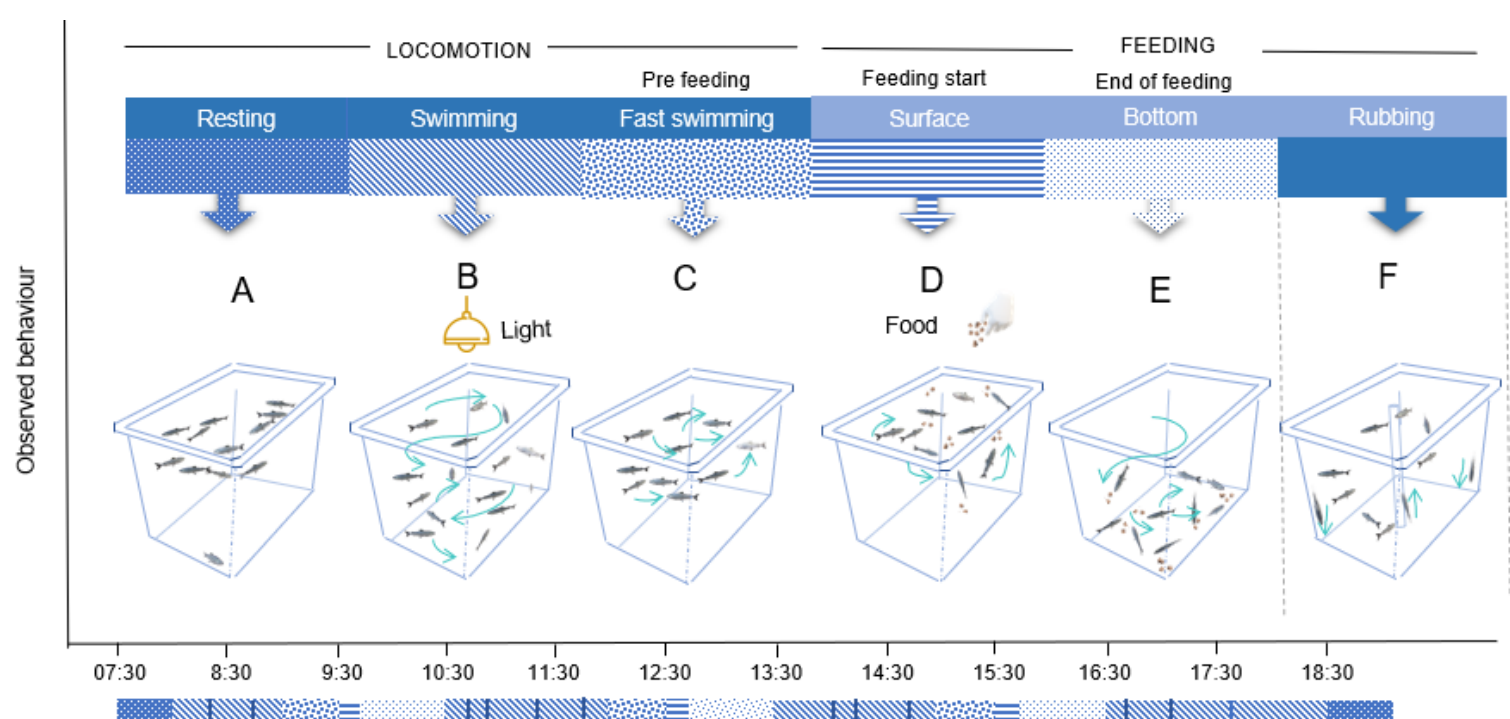

214 Figure 1. Behavioural patterns observed in Mugil cephalus in captivity. The color variation represents each

215 behavioural pattern exhibited by the fish in chronological order during the observation period (7:30 - 18:30

216 hours).

\section{Feeding}

Surface feeding. When feed was offered, fish quickly approached and ingested a maximum number of pellets. However, it was also noted that after capturing the pellets, fish frequently spitted it into the water. During the feeding frenzy, mullets showed multidirectional movements around the food. In addition, a cooperative event between fish was observed in which animals that first consumed pellets, moved immediately to another point in the water column, allowing other individuals to rise at the surface to feed. Besides, no signs of aggression or dominance over food were detected (Fig. 1-D, Table 1).

Bottom feeding. After the food was sank, grey mullet began a second feeding event in which they consumed the food in the bottom of the tank in a vertical position. In this context, fish were observed to explore the bottom of the tank searching for uneaten pellets, and constantly interact with other fish, but no aggressive behaviour were neither observed (Fig. 1-E, Table 1). Unlike surface feeding, food consumed at the bottom of the tank was swallowed and not spited into the 232 water.

Rubbing. This behavioural was distinctive of fish by rubbing their mouths against the walls 
235 a vertical position with the pectoral fins close to the body. Rubbing was observed individually or 236 in group (less than $60 \%$ of the fish) in different occasions along the day. (Fig. 1-F, Table 1).

238 Table 1. Description of the behavioural patterns observed in Mugil cephalus.

Behaviour pattern

Resting

Swimming

Fast swimming

Surface feeding

Bottom feeding

Rubbing
Maintained a stationary position or slow swimming

Fluid and constant swimming in group or individual

Subcarangiform locomotion

Capture pellets on the tank surface with multidirectional movements that allow passage to other fish for that can feed

Complete exploration of the tank bottom until the intake of all the food offered

The fish rub their mouths against the tank surfaces in a vertical position with shaky movements type zigzag

No statistical differences $(p>0.05)$ were detected in the frequencies of the six behavioural 243 variables analysed among the tanks (Table 2). Specifically, no significant differences were 244 detected for resting ( $p=0.124)$, swimming $(p=0.064)$, fast swimming $(p=0.519)$, surface feeding $245(p=0.122)$ and rubbing behaviour $(p=0.053)$. Fish from tank 2 presented significant higher 246 frequencies in bottom feeding than fish from tank $3(p=0.026)$. Therefore, the results suggest that 247 grey mullet were successfully adapted to captivity, since their behavioural tendencies were similar among tanks. 
253 Table 2. Frequencies observed for the different behaviour patterns expressed in juvenile Mugil cephalus 254 in captivity. $\bar{X}=$ mean observed frequencies \pm standard deviation; $\mathrm{CV}=$ coefficient of variation. Values in 255 bold represent significant differences from the MANOVA test.

\begin{tabular}{|c|c|c|c|c|c|c|}
\hline Category & Behaviour & Tank & $\begin{array}{c}\text { Frequencies per } \\
\text { tank } \\
(\overline{\mathrm{X}} \pm \mathrm{SD})\end{array}$ & $\begin{array}{c}\text { Mean } \\
\text { frequencies } \\
(\overline{\mathrm{X}} \pm \mathrm{SD})\end{array}$ & $\begin{array}{l}\text { C.V } \\
(\%)\end{array}$ & $p$ value \\
\hline \multirow{10}{*}{ Locomotion } & & 1 & $8.33 \pm 1.68$ & & 20 & \\
\hline & Resting & 2 & $8.80 \pm 2.04$ & $8.11 \pm 2.20$ & 23 & 0.124 \\
\hline & & 3 & $7.20 \pm 2.62$ & & 36 & \\
\hline & & 1 & $19.40 \pm 1.40$ & & 7 & \\
\hline & & & & & & \\
\hline & Swimming & 2 & $18.73 \pm 2.60$ & $18.56 \pm 2.23$ & 14 & 0.064 \\
\hline & & 3 & $17.53 \pm 2.23$ & & 13 & \\
\hline & & 1 & $28.67 \pm 1.84$ & & 6 & \\
\hline & Fast swimming & 2 & $27.73 \pm 3.62$ & $28.44 \pm 2.96$ & 13 & 0.519 \\
\hline & & 3 & $28.93 \pm 3.22$ & & 11 & \\
\hline \multirow{9}{*}{ Feeding } & & 1 & $10.53 \pm 2.20$ & & 21 & \\
\hline & Surface & 2 & $9.53 \pm 2.50$ & $10.53 \pm 2.67$ & 26 & 0.122 \\
\hline & & 3 & $11.53 \pm 3.04$ & & 26 & \\
\hline & & 1 & $27.87 \pm 1.81$ & & 6 & \\
\hline & Bottom & 2 & $29.07 \pm 3.31$ & $27.73 \pm 2.91$ & 11 & 0.026 \\
\hline & & 3 & $26.27 \pm 2.87$ & & 11 & \\
\hline & & 1 & $7.00 \pm 1.41$ & & 20 & \\
\hline & Rubbing & 2 & $5.60 \pm 1.45$ & $6.18 \pm 1.66$ & 26 & 0.053 \\
\hline & & 3 & $5.93 \pm 1.87$ & & 32 & \\
\hline
\end{tabular}




\section{Discussion}

This study described for the first time the common behaviour of juvenile M. cephalus under

260 captive. Overall, mullets are individuals with most activity during daytime due their high rates of 261 locomotion, swimming, social interactions during the day, which decrease immediately after lights 262 were turned off, as a transition to resting behaviour. In this context, Helfman (1986) suggested that 263 the behaviour in animals, such as: feeding, breeding, aggregations and resting, are influenced by 264 the artificial light alternation (light and dark) as was the case for this fish species.

\section{Locomotion}

The locomotor activity of grey mullet started with a resting behaviour or slow swimming, registered during the first minutes of the day (between 07:30 to 08:00 hours) and when lights were

270 turned off (between 18:30 to 19:00 hours). Bolgan et al. (2016) described a similar resting 271 behaviour in the arctic charr (Salvelinus alpinus) held in captivity. Moreover, authors classified 272 resting behaviour as a state of inactivity, in which fish held a stationary position most of the time 273 with no forward locomotion. Similarly, Ibarra-Zatarain \& Duncan (2015) reported that gilthead 274 seabream tended to swim slowly either alone or in small groups around the tank during early 275 morning (08:30 hours). Likewise, Park et al. (2018) reported the same resting behaviour in the 276 Korean endemic cobitid (Iksookimia hugowolfeldi) in the wild. Killen et al. (2016) have suggested 277 that resting behaviour is associated to energy conservation. Also, Zimerman et al. (2008) and Elbaz 278 et al. (2013) have described that prolonged periods of behavioural quiescence could be defined as 279 sleep in fish. Those authors pointed out that when fish decrease locomotor activity and metabolic 280 rate in order to save energy. Therefore, energy is conserved to be allocated for functional activities, 281 such as feeding, growing or reproduction, which are important biological parameters for 282 aquaculture.

The second locomotor pattern analysed, swimming behaviour, was the most common in grey 285 mullet juveniles and it was characterized by a constant movement of the fish day light hours. 286 According to different studies, this conduct has been typically described for other fish species and 287 is linked to their physiology. For example, Farwell \& McLaughlin (2009) and Brownscombe et al. 
288 (2017) suggested that constant swimming behaviour is adaptive to environment and might be 289 linked to biological functions such as: metabolism, respiration and digestion. A similar conduct to 290 that described in the present study was reported by Ibarra-Zatarain \& Duncan (2015), whom 291 observed that gilthead seabream (Sparus aurata) had a swimming activity characterized by a 292 constant swimming speed in all fish. Furthermore, swimming behaviour in white mullet (Mugil 293 curema) in their natural environment (Carvalho et al., 2007) coincided with the conduct reported 294 in the present study, is also characterized by constant swimming through the day. Downie et al. 295 (2020) mentioned that constant swimming behaviour denotes optimal welfare and a good 296 physiological condition.

Regarding fast swimming behaviour, it has been documented that locomotor activity tends 299 to increase when it is associated to behaviours such as: feeding, foraging and mating in captivity 300 or predator avoidance and migration in the wild (Brownscombe et al., 2017). Therefore, the fast 301 swimming behaviour exhibited by M. cephalus in captivity, may be related to an anticipatory 302 activity similar to what happens in other aquaculture species. For example, gilthead seabream 303 (Montoya et al., 2010) and tambaqui (Colossoma macropomum) (Fortes-Silva et al., 2018) showed 304 an increased or anticipatory swimming activity before feeding. In a different context, other studies 305 have reported that fast swimming, could be associated fast growing fish (Palstra et al., 2010), as 306 they present optimal muscular-skeletal development and osmoregulation (Huntingford and Kadri, 307 2013) and exhibits stress resistance (Martins et al., 2012).

308

\section{Feeding}

Mullets showed two distinctive feeding behaviours. First, individuals showed a preference 312 to swallow pellets in the surface of water. This initial feeding reaction could represent an intuitive 313 strategy securing food (Montoya et al., 2010); as reported in European seabass (Dicentrarchus 314 labrax) (Azzaydi et al., 1998) and Parachaeturichthys ocellatus (Paniker, 2020). Moreover, it is 315 known that feeding fish regularly, like in aquaculture rearing conditions, induces an internal 316 mechanism of synchronization with food. Additionally, Lall \& Tibbetts (2009) proposed that the 317 feeding behaviour in fish is associated to cognition, similarly to birds and mammal. Therefore, it 
318 is possible that grey mullet (Mugil cephalus) adapts its behaviour to fixed schedules of feeding in

319 captivity conditions.

320

After grey mullets consumed the pellets in the water surface, it was observed that some 322 individuals frequently spitted out the pellets that they have just swallowed resulting in approximately $60 \%$ of the offered food sinking to the bottom of the tank when second feeding 324 started. This behaviour lasted until fish consumed all the pellets and it was accompanied by 325 exploration and social interactions. Islam et al. (2009) suggested that grey mullet is a bottom 326 feeder, that exhibits herbivore preferences, based on gut content, which may explain the presence 327 of bottom feeding in captivity. Similar results have been found by Anders et al. (2017) and Park 328 et al. (2018) in cod (Gadus morhua) and the Korean endemic cobitid, suggesting that this 329 preference to feed is associated with their natural feeding habits. When analysing the frequencies 330 of this behavioural variable, significant differences were detected among tanks. This variation 331 could be related to feeding practices, since fish were fed ab-libitum and, thus, it is possible that 332 fish did not receive the same amount of feed. To confirm this previous assumption, it will be 333 important to evaluate different food rations for this fish species, as suggested by Wassef et al. 334 (2001) who reported that $4 \%$ of total biomass in food, might result in similar behavioural 335 frequencies.

On the other hand, rubbing behaviour has been related to the lifestyle and feeding strategy 338 of this fish species (Almada et al., 1999), and similar observation was reported in the korean 339 endemic cobitid. This fish species showed a zig zag swimming behaviour which was associated 340 with their habitat and feeding behaviour (Park et al., 2018). Additionally, Islam et al. (2009) 341 described that mullet feed in the wild mainly with algae and detritus; thus, the adaptation of feeding 342 behaviour in the Mugilidae family is instinctively based on searching for food at the bottom or 343 edges by rubbing its body to graze and ingest phytoplankton and other detritus (Bowen, 1984).

344 Therefore, by showing this kind of behaviour, grey mullet may be adapting to captivity, hence, 345 this behavioural response can be used as a measurement of optimal performance of the species. 
349 behaviour when consuming food swimming in a synchronized way, allowing all individuals to eat.

350 Wey et al. (2008) described that social animals live and interact together, forming complex social 351 relationships and structures that can have advantageous to obtain resources (i.e. food, feeding 352 areas, others). Unlike, in other reared species such as the rainbow trout there is a marked 353 competition for resources, (Øverli et al., 2004) or the presence of dominance in sole, conferring 354 an advantage of some fish over others access to the food (Fatsini et al., 2017). Therefore, the 355 absence of hostile behaviours in the grey mullet could be considered as an important factor for the 356 aquaculture of this fish species.

\section{Conclusion}

In conclusion, behaviours are responses exhibited by fish in their environment to access to resources, which allow them to meet their basic requirements and survive (Føre et al., 2018).

362 Considering that welfare of reared animals generally leads to a production of quality, it is relevant 363 to know the expression of natural behaviours as a forecasting model of welfare status and 364 physiological performance (Huntingford, 2004). Thus, this research described the typical 365 behavioural repertoire of mullet juveniles (Mugil cephalus), where all the functional categories 366 observed in rearing conditions were described, that is, the usual behaviour observed in 367 chronological order in a production farm. Moreover, traits such as cognition and social behaviour 368 may pose the attraction for mullet as an attractive aquaculture species in Mexico. Thus, this study 369 contributes to the knowledge of the species for a correct management of the biological processes 370 and to implement rearing protocols that will improve aquaculture production of a species of 371 economic interest. Moreover, this study represents a starting point for any behavioural study in 372 mullet and a reference for comparison with others studies in the wild and under stress conditions 373 for this species.

\section{References}

Aldana JM, 2015. Posibilidades de cultivo de nuevas especies marinas en el área mediterránea. Doctoral dissertation. Univ. Politécnica de Madrid, Spain. 175 pp. 
Almada VC, Henriques M, Gonçalves EJ, 1999. Ecology and behaviour of reef fishes in the temperate north-eastern Atlantic and adjacent waters. In: Behaviour and conservation of littoral fishes; Almada VC, Oliveira RF, Gonçalves EJ (eds.). pp 33-69, ISPA, Lisboa.

Altman J, 1974. Observational study of behavior: sampling methods. Behaviour 49 (3-4): 227266. https://doi.org/10.1163/156853974X00534

Anders N, Fernö A, Humborstad OB, Løkkeborg S, Utne-Palm AC, 2017. Species specific behaviour and catchability of gadoid fish to floated and bottom set pots. ICES J Mar Sci 74

Ashley PJ, 2007. Fish welfare: current issues in aquaculture. Appl Anim Behav Sci 104: 199-235. https://doi.org/10.1016/j.applanim.2006.09.001

Azzaydi M, Madrid JA, Zamora S, Sánchez-Vázquez FJ, Martinez FJ, 1998. Effect of three 391 feeding strategies (automatic, ad libitum demand-feeding and time-restricted demandfeeding) on feeding rhythms and growth in European seabass (Dicentrarchus labrax L.). Aquaculture 163 (3-4): 285-296. https://doi.org/10.1016/S0044-8486(98)00238-5

Baran NM, Streelman JT, 2020. Ecotype differences in aggression, neural activity and behaviorally relevant gene expression in cichlid fish. Genes Brain Behav 19 (6): e12657. https://doi.org/10.1111/gbb.12657

Besbes R, Benseddik AB, Kokokiris L, Changeux T, Hamza A, Kammoun F, Missaoui H, 2020. Thicklip (Chelon labrosus) and flathead (Mugil cephalus) grey mullets fry production in Tunisian aquaculture. Aquac Rep 17: 100380. https://doi.org/10.1016/j.aqrep.2020.100380

400 Bolgan M, O'Brien J, Gammell M, 2016. The behavioural repertoire of Arctic charr (Salvelinus alpinus (L.)) in captivity: a case study for testing ethogram completeness and reducing observer effects. Ecol Freshw Fish 25 (2): 318-328. https://doi.org/10.1111/eff.12212

Bowen SH, 1984. Detritivory in neotropical fish communities. In: Evolutionary ecology of neotropical freshwater fishes; Zaret TM (ed.). pp: 59-66. Springer, Dordrecht. https://doi.org/10.1007/978-94-015-7682-6_4

406 Brownscombe JW, Cooke SJ, Algera DA, Hanson KC, Eliason EJ, Burnett NJ, Danylchuk AJ, 407 Hinch SG, Farrell AP, 2017. Ecology of exercise in wild fish: integrating concepts of 
410 Carvalho CD, Corneta CM, Uieda VS, 2007. Schooling behavior of Mugil curema (Perciformes: Mugilidae) in an estuary in southeastern Brazil. Neotrop Ichthyol 5: 81-83. 9. http://dx.doi.org/10.1590/S1679-62252007000100012

Castanheira MF, Conceição LE, Millot S, Rey S, Bégout ML, Damsgård B, Kristiansen T, Höglund E, Øverli Ø, Catarina IM, Martins CI, 2017. Coping styles in farmed fish: consequences for aquaculture. Rev Aquac 9 (1): 23-41. https://doi.org/10.1111/raq.12100

Colín A, Hernández-Pérez Z, Guevara-Chumacero LM, Castañeda-Rico S, Serrato-Díaz A, Ibáñez https://doi.org/10.1007/s00227-019-3622-1

Crosetti D, Blaber SJ (eds), 2015. Biology, ecology and culture of grey mullets (Mugilidae). CRC

Raton.

https://books.google.com.mx/books?hl=es\&lr=\&id=GAhCCwAAQBAJ\&oi=fnd\&pg=PP1

Crosetti D, 2015. Current state of grey mullet fisheries and culture In: Biology, ecology and culture of grey mullets (Mugilidae); Crosetti D, Blaber SJ (eds.). pp: 398-450. CRC Press, Boca Raton.

Downie AT, Illing B, Faria AM, Rummer JL, 2020. Swimming performance of marine fish larvae: review of a universal trait under ecological and environmental pressure. Rev Fish Biol Fish 30 (1): 93-108. https://doi.org/10.1007/s11160-019-09592-w

Elbaz I, Foulkes NS, Gothilf Y, Appelbaum L, 2013. Circadian clocks, rhythmic synaptic plasticity and the sleep-wake cycle in zebrafish. Front Neural Circuit 7: 9. 
FAO, 2020a. Cultured aquatic species fact sheets. Food and Agriculture Organization of the United Nations. Available in: http://www.fao.org/fishery/culturedspecies/Mugil_cephalus/es. [22 February 2021].

FAO, 2020b. Fishhery and Aquaculture Statistics, Global production 1950-2018 (FishstatJ). Food and Agriculture Organization of the United Nations. Avaliable in: http://www.fao.org/fishery/. [Update september 2020].

Farwell M, McLaughlin RL, 2009. Alternative foraging tactics and risk taking in brook charr (Salvelinus fontinalis). Behav Ecol 20: 913-921. https://doi.org/10.1093/beheco/arp059

Fatsini E, Rey S, Ibarra-Zatarain Z, Mackenzie S, Duncan NJ, 2017. Dominance behaviour in a non-aggressive flatfish, Senegalese sole (Solea senegalensis) and brain mRNA abundance of selected transcripts. PloS one 12 (9): e0184283. https://doi.org/10.1371/journal.pone.0184283

Fortes-Silva R, Valle SVD, Lopéz-Olmeda JF, 2018. Daily rhythms of swimming activity, synchronization to different feeding times and effects on anesthesia practice in an Amazon fish species (Colossoma macropomum). Chronobiol Int 35 (12): 1713-1722. https://doi.org/10.1080/07420528.2018.1509078

Føre M, Frank K, Norton T, Svendsen E, Alfredsen JA, Dempster T, Eguiraun H, Watson W, Stahl A, Sunde LM, Schellewald C, Skøie KR, Alver MO, Berckmans D, 2018. Precision fish farming: A new framework to improve production in aquaculture. Biosyst Eng 173, 176193. https://doi.org/10.1016/j.biosystemseng.2017.10.014

Gisbert E, Mozanzadeh MT, Kotzamanis Y, Estévez A, 2016. Weaning wild flathead grey mullet (Mugil cephalus) fry with diets with different levels of fish meal substitution. Aquaculture 462: 92-100. https://doi.org/10.1016/j.aquaculture.2016.04.035

Helfman GS, 1986. Fish behaviour by day, night and twilight. In: The behaviour of teleost fishes; Pitcher TJ, (ed.). pp: 366-387. Springer, Boston, MA. https://doi.org/10.1007/978-1-4684$\underline{8261-414}$

Hosseini Aghuzbeni SH, Hajirezaee S, Matinfar A, Khara H, Ghobadi M, 2017. A preliminary study on polyculture of western white shrimp (Litopenaeus vannamei) with mullet (Mugil 
cephalus): an assessment of water quality, growth parameters, feed intake efficiency and survival.

Appl

Anim Res

45

(1):

247-251. https://doi.org/10.1080/09712119.2016.1150845.

467 Huntingford FA, 2004. Implications of domestication and rearing conditions for the behaviour of 468 cultivated fishes. J Fish Biol 65: 122-142. https://doi.org/10.1111/j.0022-1112.2004.00562.X

469 Huntingford FA, Kadri S, 2013. Exercise, stress and welfare. In: Swimming Physiology of Fish; 470 Palstra AP, Planas JV (eds.). pp: 161-174. Springer, Berlin, Heidelberg. https://doi.org/10.1007/978-3-642-31049-2_7

Ibarra-Zatarain Z, Duncan N, 2015. Mating behaviour and gamete release in gilthead seabream http://dx.doi.org/10.5424/sjar/2015131-6750

Islam R, Hossain MB, Das NG, Rafi RU, 2009. Food and feeding behaviour of grey mullet Mugil cephalus (L), of Bangladesh coastal water. Bangl J Prog Sci Tech 7: 273-276. https://www.researchgate.net/publication/230562308

Keene AC, Appelbaum L, 2019. Sleep in Fish Models. In: Handbook of Behavioral Neuroscience; Dringenberg HC (ed.). pp: 363-374. Elsevier. https://doi.org/10.1016/B978-0-12-813743$\underline{7.00024-4}$

Killen SS, Glazier DS, Rezende EL, Clark TD, Atkinson D, Willener AS, Halsey LG, 2016. Ecological influences and morphological correlates of resting and maximal metabolic rates across teleost fish species. Am Nat 187 (5): 592-606. https://doi.org/10.5061/dryad.dg6jk behaviour as an indicator of low growth rate and impaired welfare in Atlantic halibut (Hippoglossus hippoglossus L.) reared at three stocking densities. Aquaculture 230 (1-4): 137-151. https://doi.org/10.1016/S0044-8486(03)00436-8 
491 Lahitte HB, Ferrari H, Lázaro L, 2002. Sobre el etograma 1: del etograma como lenguaje al 1 enguaje de los etogramas. Rev Etol 4 (2): 129-141. http://pepsic.bvsalud.org/scielo.php?script=sci_arttext\&pid=S1517-28052002000200005

494 Lall SP, Tibbetts SM, 2009. Nutrition, feeding, and behavior of fish. Vet Clin North Am Exot Anim Pract 12 (2): 361-372. https://doi.org/10.1016/j.cvex.2009.01.005

López-Olmeda JF, Montoya A, Oliveira C, Sánchez-Vázquez FJ, 2009. Synchronization to light and restricted-feeding schedules of behavioral and humoral daily rhythms in gilthead sea bream (Sparus aurata). Chronobiol int $26 \quad$ (7): 1389-1408. $\underline{\text { https://doi.org/10.3109/07420520903421922 }}$

500 Mahanty S, Maclean JD, Cross JH, 2011. Liver, lung and intestinal fluke infections. In: Tropical infectious diseases, 3rd ed; Guerrant RL, Walker DH, Weller, PF (eds.). pp: 854-862.

504 Marsh DM, Hanlon TJ, 2004. Observer gender and observation bias in animal behaviour research: experimental tests with red-backed salamanders. Anim Behav 68 (6): 1425-1433. https://doi.org/10.1016/j.anbehav.2004.02.017

507 Martínez FP, Bermúdez L, Aznar MJ, Moyano FJ, 2019. Evaluation of Enzyme Additives on the 508 Nutritional Use of Feeds with a High Content of Plant Ingredients for Mugil cephalus. Fishes 4 (4): 56. https://doi.org/10.3390/fishes4040056

513 Mas-Muñoz J, Komen H, Schneider O, Visch SW, Schrama JW, 2011. Feeding behaviour, swimming activity and boldness explain variation in feed intake and growth of sole (Solea solea) reared in captivity.

PLoS

One 6: $\quad$ e21393.

517 McDonnell SM, Poulin A, 2002. Equid play ethogram. Appl Anim Behav Sci 78 (2-4): 263-290. 
519 Mondal A, Bhattacharya S, Mitra A, Sundaray J, Mohanty RK, 2020. Effect of different species combinations of finfish with black tiger shrimp (Penaeus monodon) on production performance, economic efficiency and water productivity in extensive brackishwater polyculture system. Aquac Res 1-12. https://doi.org/10.1111/are.14861

Montoya A, López-Olmeda JF, Garayzar ABS, Sánchez-Vázquez FJ, 2010. Synchronization of daily rhythms of locomotor activity and plasma glucose, cortisol and thyroid hormones to feeding in Gilthead seabream (Sparus aurata) under a light-dark cycle. Physiol Behav 101(1): 101-107. https://doi.org/10.1016/j.physbeh.2010.04.019

Myrberg Jr AA, 1972. Ethology of the bicolor damselfish, Eupomacentrus partitus (Pisces: Pomacentridae): a comparative analysis of laboratory and field behaviour. Anim Behav Monogr 5: 197-283. https://doi.org/10.1016/0003-3472(72)90002-4

530 Øverli Ø, Korzan WJ, Höglund E, Winberg S, Bollig H, Watt M, Forster G, Barton B, Øverli E, 531 Renner KJ, Summers CH, 2004. Stress coping style predicts aggression and social dominance in rainbow trout. Horm Behav 45 (4): 235-241.

534 Panicker B, 2020. Morphology, Food and Feeding Habit of Goby Fish, Parachaeturichthys ocellatus from the Creeks of Mumbai. Int J Eng Sci. Manag Res. 3 (11): 95-100. https://doi.org/10.47607/ijresm.2020.382

537 Palstra AP, Tudorache C, Rovira M, Brittijn SA, Burgerhout E, Van den Thillart GEE, Spaink HP, Planas JV, 2010. Establishing zebrafish as a novel exercise model: swimming economy, swimming-enhanced growth and muscle growth marker gene expression. PLoS One 5 (12): e14483. https://doi.org/10.1371/journal.pone.0014483

541 Park CW, Kim JG, Yun SW, Kim HT, Park JS, Choi WS, Cho YJ, Lee YJ, Park JY, 2018. Habitat, diet, feeding and resting behaviour of the Korean endemic cobitid Iksookimia hugowolfeldi (Cobitidae, Pisces) in the wild. J Vertebr Biol 67 (1): 1-8. https://doi.org/10.25225/fozo.v67.i1.a2.2018

545 Pink JR, Fulton CJ, 2014. Right tools for the task: intraspecific modality in the swimming 546 behaviour of coral reef fishes. Mar Biol 161 (5): 1103-1111. https://doi.org/10.1007/s00227- 
548 Ramos-Júdez S, Chauvigné F, González-López WA, Rosenfeld H, Cerdá J, Giménez I, Duncan N, 2021. Providing recombinant gonadotropin-based therapies that induce oogenesis from previtellogenic oocytes to produce viable larvae in a teleost, the flathead grey mullet (Mugil cephalus). Aquaculture:

Article

ID

736418. https://doi.org/10.1016/j.aquaculture.2021.736418

553 Robles R, Mylonas CC, 2017. Exploring the biological and socio-economic potential of new/emerging candidate fish species for the expansion of the European aquaculture industry. Impact 2017 (3): 14-16. https://doi.org/10.21820/23987073.2017.1.14

Rodríguez SE, 2018. Preselección de especies para la piscicultura marina en el Pacífico Sur de México. Ciencia ergo-sum 25: 1-31. https://doi.org/10.30878/ces.v25n1a6

Rowland WJ, 1999. Studying visual cues in fish behavior: a review of ethological techniques. Environ Biol Fishes 56: 285-305. https://doi.org/10.1023/A:1007517720723

Saraiva J, Arechavala-Lopez P, Castanheira MF, Volstorf J, Heinzpeter Studer B, 2019. A Global 561 Assessment of Welfare in Farmed Fishes: The FishEthoBase. Fishes 4 (2): 30. https://doi.org/10.3390/fishes4020030

Saleh M, 2008. Capture-based aquaculture of mullets in Egypt. In: Capture-based aquaculture Global overview; Lovatelli A, Holthus PF (eds.). pp: 109-126. FAO Fish Tech Pap, Rome.

565 Soto D, 2009. Integrated mariculture: a global review. FAO, Rome, Italy. 529 pp.

Talukdar A, Deo A. D, Sahu NP, Sardar P, Aklakur M, Prakash S, Nazeema S, Kumar S, 2020. Effects of dietary protein on growth performance, nutrient utilization, digestive enzymes and physiological status of grey mullet, Mugil cephalus L. fingerlings reared in inland saline

570 Thomsen H, Jensen TH, Ydesen K, Madsen N, 2020. Use of Ethograms to analyse Shoaling Behaviour of Mackerel (Scomber scombrus) in an Aquarium. Genet Biodivers J 131-144.

573 Vera LM, De Pedro N, Gomez-Milan E, Delgado MJ, Sanchez-Muros MJ, Madrid JA, SanchezVazquez FJ, 2007. Feeding entrainment of locomotor activity rhythms, digestive enzymes 
and neuroendocrine factors in goldfish. Physiol Behav 90 (2-3): 518-524. https://doi.org/10.1016/j.physbeh.2006.10.017

577 Wassef EA, El Masry MH, Mikhail FR., 2001. Growth enhancement and muscle structure of striped mullet, Mugil cephalus L., fingerlings by feeding algal meal-based diets. Aquac Res 32 (1): 315-322. https://doi.org/10.1046/j.1355-557x.2001.00043.x

580 Wey T, Blumstein DT, Shen W, Jordán F, 2008. Social network analysis of animal behaviour: a

581 promising tool for the study of sociality. Anim Behav 75 (2): 333-344. https://doi.org/10.1016/j.anbehav.2007.06.020

583 Whitfield AK, Panfili J, Durand JD, 2012. A global review of the cosmopolitan flathead mullet Mugil cephalus Linnaeus 1758 (Teleostei: Mugilidae), with emphasis on the biology, genetics, ecology and fisheries aspects of this apparent species complex. Rev Fish Biol Fisher 22 (3): 641-681. https://doi.org/10.1007/s11160-012-9263-9

587 Zimmerman JE, Naidoo N, Raizen DM, Pack AI, 2008. Conservation of sleep: insights from non-

(7): $\quad 371-376$. 